\title{
GIMLET EYE
}

\author{
Cyril Dabydeen
}

\begin{abstract}
Ways of reckoning in another look-around, and about where I said I've come from.
\end{abstract}

She flutters her eyes, and it's laughter, or just a whim-a remonstrance I will bear

Breathing harder, the body's own way: what I bring to you, turning in another direction.

Now again waving to you-believe me, coming to grips with reality, nothing less.

Being defenseless from the start, I must let you know-turning around once again. 